\title{
US energy agency strengthens protections for scientists
}

\section{Researchers given greater leeway on speaking to the press and publishing their findings.}

\section{BY ERIN ROSS}

$\mathrm{T}$ he US Department of Energy (DOE) released new guidelines on 11 January to protect researchers from political interference - a move that many say is long overdue.

"DOE officials should not and will not ask scientists to tailor their work to any particular conclusion," says energy secretary Ernest Moniz.

The revised guidelines come amid concerns that president-elect Donald Trump's administration will seek to limit federal support for science, including climate-change research. In December, Trump's team asked the DOE for the names of employees who have worked on climate-change issues; the department refused and Trump staffers later disavowed the request.

Moniz says the new policy is not a response to that incident or to Trump's election, and has been in the works for a while.

But Wendy Wagner, a law professor at the University of Texas at Austin, thinks that the timing is significant. "The DOE might feel that if they don't get this policy out now, it won't be implemented," she says.

The plan allows scientists to publicly state their opinions on science and policy if they make clear that they are not speaking for the government. It requires researchers to notify their supervisors if they speak to the media or publish their findings, but does not require them to seek approval for such activities.

"It makes it absolutely clear that notification is the only thing required," says Wagner. "The tenor of the entire policy seems to be full bore about giving scientists and technical people the complete freedom to speak about their research and how it intersects with policy."

"The old policy was extremely vague, bare bones and had no structure for implementation."

That includes sharing their opinions online. The statement says that employees have the "right" to express personal opinions in digital media, and says that they are "encouraged" to discuss their scientific research openly. Wagner believes that this includes the use of social media such as Facebook.

The plan - which applies to DOE employees, contractors and grant recipients - also calls for the department to appoint an independent ombudsperson to handle complaints. And it clarifies and strengthens protections for whistleblowers.

That is a major shift from the DOE's previous scientific-integrity policy, issued in 2012. That policy applied only to DOE employees, and required them to coordinate with their supervisors before talking to the media, and to receive approval before publishing their findings in peer-reviewed journals.

"The old policy was extremely vague, bare bones and had no structure for implementation," says Michael Halpern, deputy director of the Center for Science and Democracy at the Union of Concerned Scientists in Cambridge, Massachusetts. "When rights are not explicit, scientists that share personal opinions can be retaliated against."

But it will be up to the next administration to implement the plan. Trump takes office on 20 January, and his pick for energy secretary former Texas governor Rick Perry — could soon be confirmed by the Senate.

"The Senate really needs to get details from Governor Perry, when they go through the confirmation process, about the specific implementation plans he has to ensure that this becomes a reality," Halpern says. .
BY MIĆO TATALOVIĆ AND NENAD JARIĆ DAUENHAUER

$\mathrm{I}$ $n$ a plagiarism scandal in Croatia, the country's highest-level research-ethics committee is clashing with its science minister - who says he won't step down after the committee found he had copied another scholar's work. Scientists say that the case raises questions about academic integrity at the top of a research system that is already riven with misconduct allegations.
Pavo Barišić, a philosopher at the University of Split, became Croatia's science minister in October 2016. Soon after that, Croatian media began reporting allegations that Barišić had reproduced text without attributing other scholars in a review article that first appeared in 2008. The charges were old - they had been raised by four other philosophers in 2011 but Croatia's parliament-appointed Committee for Ethics in Science and Higher Education (CESHE) said it would investigate.

On 9 January, the committee's report was leaked to the press. The CESHE, which has not yet formally published the report, concluded that a footnote in Barišićs article used text from a blogpost by a US international-affairs specialist, Stephen Schlesinger, at the Century Foundation in New York City.

For months, Barišić had maintained that he had done nothing wrong, even as academics called for his resignation. But by December 2016 he had changed his stance. He told journalists that he had taken text from Schlesinger without attribution, and had apologized to 